\title{
The Significance of Utilising Renewable Energy Options into the Libyan Energy Mix
}

\author{
${ }^{1}$ Ahmed M.A. Mohamed, ${ }^{1}$ Amin Al-Habaibeh, \\ ${ }^{2}$ Hafez Abdo and ${ }^{3}$ Mohammad Juma R. Abdunnabi \\ ${ }^{1}$ Advanced Design and Manufacturing Engineering Centre, \\ School of Architecture, Design and the Built Environment, \\ Nottingham Trent University, Burton Street, Nottingham NG1 4BU, UK \\ ${ }^{2}$ Nottingham Business School, \\ ${ }^{3}$ Department of Thermal Energy Conversion, \\ Center for Solar Energy Research and Studies (CSERS), Libya
}

Received 2013-07-03, Revised 2013-07-22; Accepted 2013-07-24

\begin{abstract}
This study is to investigate the financial and technological challenges and opportunities facing the utilisation of renewable energy resources in Libya. The work investigates the availability of different renewable energy resources in Libya and the practicality of implementing some of these options. The study aims to study and identify the contribution of renewable energy in the mixture of total energy supply in Libya. It also investigates the essential legislation in the field of energy, which contributes to supporting the expansion of the implementation of renewable energy as an alternative energy and proposing the necessary recommendations for the necessary investment. This study integrates data and information for literature review and secondary data from field visits to Libya to paint a comprehensive picture in relation to energy demand and consumption in Libya. Based on the literature review and secondary data, it is evident, despite the recent political changes in Libya that renewable energy is still strategically of high importance. Solar and wind energy a reconsidered the main sources of renewable energy in addition to wave and tidal energy. In addition, it has been found that energy demand is increasing in Libya and that renewable energy could be the solution to cover some of this demand. Moreover, there is a need to attract investors in renewable technologies by enhancing the infrastructure and the existing investment regulations.
\end{abstract}

Keywords: Energy Investment, Libya, Oil and Natural Gas, Renewable Energy Resources, Solar and Wind

\section{INTRODUCTION}

Libya is a crucial country in the Middle East and North Africa; this is because it occupies a strategic location in North Africa since it is located in place of links of Southern Europe with the rest of Africa and Eastern with Western Africa. Therefore, would play a major role in connecting the oil, gas and electricity international grid. Although the fact that Libya is considered as one of the oil-rich countries, it is important to secure alternative resources of energy especially it has only one type and limited energy resources (oil). This in turn can lead to maintain oil resources for future generations and to reduce pollution.

\subsection{The Problem in Context}

Many studies show that the importance of solar and wind energy as one of the best alternative to conventional energy in Libya. The industrial growth is requiring continuous operation of power plants and more fuel consumption. In addition the growth in population is causing significant increase in electricity demand all over Libya which is creating a considerable need for further investment in the infrastructure including power lines and additional power stations. This study investigates the importance of renewable energy and the possibility of its utilisation in Libya. This gives strong Corresponding Author: Hafez Abdo, Nottingham Business School, Center for Solar Energy Research and Studies (CSERS), Libya 
demand to study the feasibility and usefulness of renewable energy and the possibility of its utilisation in Libya which is the main aim of this study. The characteristic of current energy demand and the availability of renewable energy are discussed based on data provided by several government organisations.

\subsection{The State of Energy in Libya}

The main objective of this section is to explore the current and the future energy situation and structure in Libya. The current energy supply in almost all countries cannot be considered as a sustainable source of energy, as the energy costs are exponentially increasing due to the environmental issues and limitations of resources (Saleh, 2006). With regard to Libya, the conventional and main resources of energy are oil and natural gas (Ekhlat et al., 2007), not only for energy supply, but also for revenues to finance the development of the society (Eljrushi and Zubia, 1995). The country has the highest proven oil reserves than any country in Africa (Wright, 2012). The conventional resources of energy in Libya are limited as follows:

- Oil: According to Oil and Gas Journal (OGJ) Libyan proven reserves were estimated at 47.1 billion barrels as of January 2012 (Watkins, 2011), which is equivalent to 29 years of production at a rate of 1.65 million barrels per day (mbb/d) (Wright, 2012)

- According to the same source as above, the proven reserves of natural gas were estimated at 52,8 trillion cubic feet (Tcf) (Watkins, 2011), which equal to 50.8 years of production which is 1,069 billion cubic feet as indicated in the International Energy Agency (IEA) report. Figure $\mathbf{1}$ includes the African countries proven oil reserve holders 2012 and Fig. 2 shows the top African natural gas proven reserve holders, 2012 (Wright, 2012)

Both kinds of energy have continued to play a major role in the country's economy since they are an important feed stock for many industries and more than half of the energy production of oil and natural gas are exported (Eljrushi and Zubia, 1995).

According to the Libyan government, it was planned to raise the crude production capacity from 1.8 million in 2009 to 3 million barrels a day by the year 2013. The country has an additional 5 billion barrels of oil unused since they are difficult to develop or remote, accounting for $12 \%$ of its total oil reserves. The National Oil Corporation (NOC) has controlled the oil industry and manages investments in Libya through Exploration and Production Sharing Agreements (EPSA). The National refining capacity totals approximately 378 thousand barrels per day, being provided by five domestic oil refineries, all possessed by NOC (Affairs, 2010). In Libya, oil refineries require an urgent repairs and improvement. Because of Libya was incapable to import new refining technologies through the period 93-98 of trade sanctions; its refining capacity is lower than the design capacity (Mandil, 2005; Affairs, 2010). An additional responsibility of NOC is the producer of natural gas and has a control on all new discoveries. Libya has proven natural gas reserves equivalent to 1.3 billion cubic meters bcm. This amount rose significantly over the past 20 years since large investments were started to investigate new deposit. The International Energy Agency (IEA) supposes that a marketed raise in gas production from 6 billion cubic meters bcm in 2003 to $12 \mathrm{bcm}$ in 2010 and then a surge reach to $57 \mathrm{bcm}$ in the year 2030 (Affairs, 2010). With energy demand on the increase, most of Libya's existing power stations are being changed from oil to natural gas and new power plants are being established to run on natural gas. Moreover, the Libyan government is planning to expand the production of natural gas to substitute oilfired power plants with natural gas-fuelled units. Firstly is planning to maximise the quantity of oil available for export and secondly is looking to increase its natural gas exports, especially to Europe and others (Affairs, 2010; Hassin, 2009). Expansion of natural gas production is a high priority for Libya as it aims to use natural gas as an alternative to oil domestically for power generation and industrial activities and also availability of more oil for export. The natural gas production is enhanced by $180 \%$ to reach about $30 \mathrm{bcm}$ per year between 2000 and 2007 (Lmere, 2005; Tanaka, 2009). Table 1 shows the energy production by the year 2010 .

The exportation of Libyan oil and natural gas suffered a near-total disruption in the months of political unrest in early months of 2011 , as the minimal and irregular oil generation that did occur was mostly exhausted domestically. In September 2011, Libyan oil production started its recovery Fig. 3. After the gradual consolidation of control over most cites of the country by the Transitional National Council (TNC) by May 2012, crude oil production was estimated to have recovered to at least $1.65 \mathrm{mbpd}$, as the impressive pace of the sector's recovery exceeded the expectations of most industry analysts. 


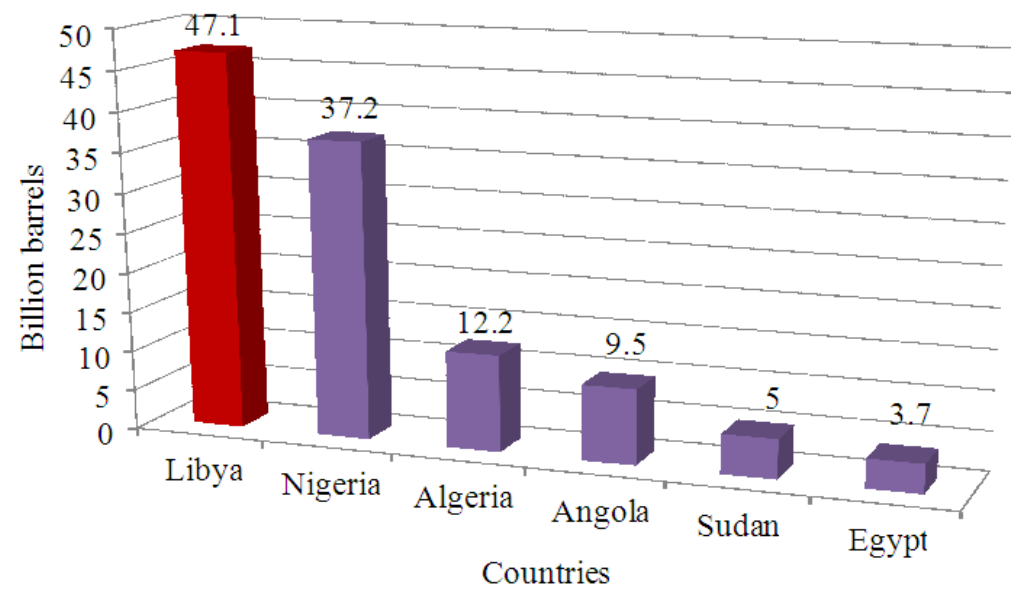

Fig. 1. African proven oil reserve holders, 2012, (Source of data: Oil and Gas journal as of January 1, 2012 online)

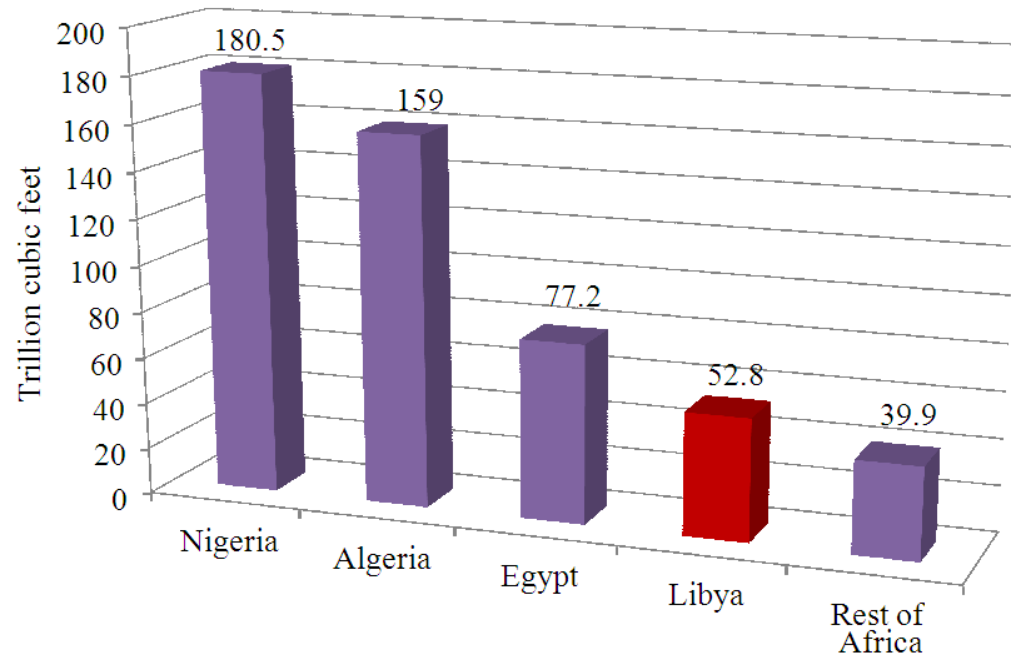

Fig. 2. Top African natural gas proven reserve holders, 2012, (Source of data: Oil and Gas Journal as of January 1, 2012)

Table 1. Energy production by the year 2010 Wright (2012) (mbpd: Million barrels per day; bcf: billion cubic feet)

\begin{tabular}{llll}
\hline Type & Production & Consumption & Export \\
\hline Oil (2010) & $1.65 \mathrm{mbpd}$ & $300 \mathrm{tbpd}$ & $1,5 \mathrm{mbpd}$ \\
Natural gas (2010) & $1,069 \mathrm{bcf}$ & $242 \mathrm{bcf}$ & $352 \mathrm{bcf}$ \\
\hline
\end{tabular}

IEA have indicated that the production of Libyan oil was interrupted for much of 2011 because of the conflict, but started to recover comparatively rapidly by the autumn of that year with the improvement of stability. It is known that the economy of Libya is dependent on hydrocarbons proposes that the sustained recovery of the energy industry will be a main cause of the country's short to medium term economic development (Wright, 2012).

\subsection{Energy Requirements}

Energy is the essential basis of human communities and the driving force for economic development. The significance of energy comes from its contribution to everyday life quality and industrial development (Hassin, 2009). The average economic growth in the period from 1995-1999 in Libya was $1.6 \%$ and the corresponding value in 2005 was $8.5 \%$ (Grein et al., 2007). In addition, the International Monetary Fund (IMF) state that, the economy increased by only $1.8 \%$ in the year 2009. This was below $3.4 \%$ increase in the year 2008 and was the worst performance since 2002 while the oil prices rebounding with the economy shrank by $1.3 \%$. 


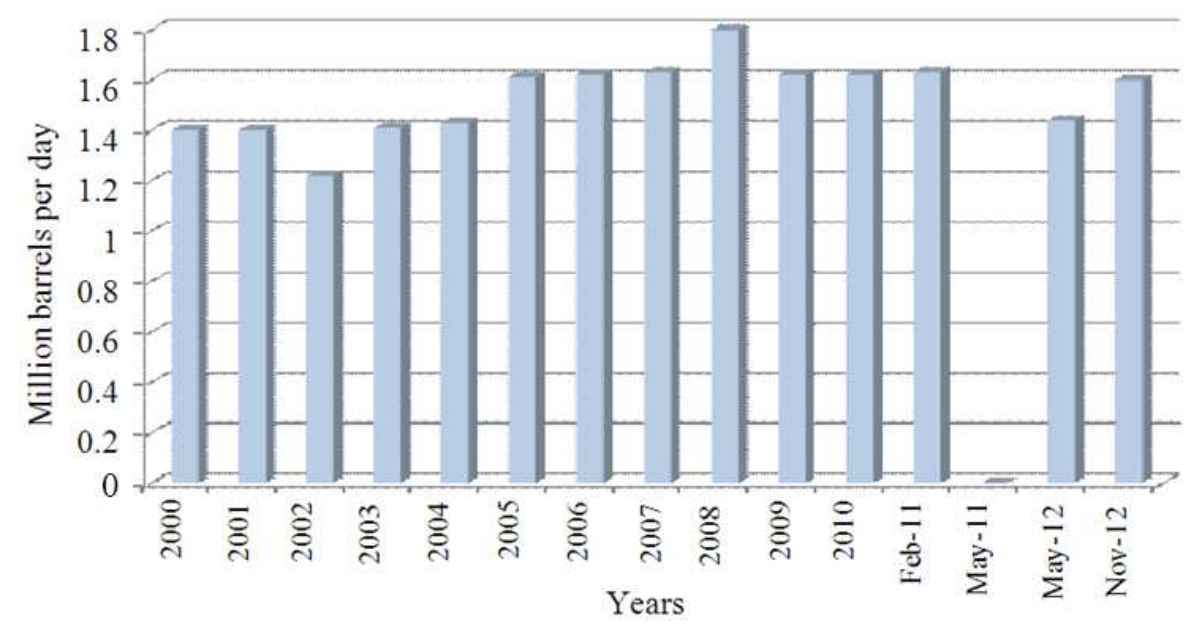

Fig. 3. Libya's Crude Oil Production, January 2000 to November 2012, (Source U.S Energy Information International Energy Statistics and Short-Term Energy Outlook 2012) (Michel, 2013)

The International Monetary Fund (IMF) and Wright (2012) believe that the economy will gather momentum and is forecasting a $5.2 \%$ advance 2010 and a $6.1 \%$ increase for 2011.

However, Organisation of the Petroleum Exporting Countries (OPEC) countries are expected to face a rise in demand as the economic growth will be reflected in change in live style and rose of energy consumption for example cooling and space heating. Consequently, the government will be forced to more efficient energy usage to overcome the growing energy cost. Otherwise, renewable energy and changed energy mix will be a challenge for the countries in the area (Grein et al., 2007). With this regard, Libyan total principal energy demand have grown at an average yearly rate of 3.3\% over the forecast period which is reaching to 43 million tonne of oil equivalent (Mtoe) in 2030. Libya's efforts expanding and facing energy demand (for both oil and natural gas) in its economy were troubled in the transformation and industrial sectors (Mandil, 2005). As far as renewable energy is considered, it is not a wellinvestigated subject in Libya due to the availability of oil as Libya is one of the leading oil exporters. Despite the fact that renewable energy such as solar and wind power as discussed next section is widely available in Libya, it is still difficult to break the dependency on oil and natural gas, not only for energy supply but also for revenues to finance the development of the society and the infrastructure (Mohamed et al., 2013). It is essential to map the current energy demand in Libya; this will be the subject of the next section.

\subsection{Energy Demand in Oil and Natural Gas Sector}

With regards to energy consumption in Libya, it is expected that there will be a significant increase in the near future, driven mostly by rapid economic growth. According to the Reference Scenario of the World Energy Outlook 2005 of the International Energy Agency (IEA), crucial energy demand will grow by 28 million tonne of oil equivalent (Mtoe) between 2003 and 2030 , rising at an average annual rate of $3.6 \%$ (Mandil, 2005). In 2006, total major energy demand in Libya was 18 Mtoe. Per capita energy consumption was approximately 2.9 tonne of oil equivalent (toe) and this is higher than the North African average of 0.9 toe. The total energy demand has climbed to 9.1 TMT in 2003 from 5.4 Thousand Metric Tons (TMT) in 1990, with largest consumption peak of $60 \%$ of total production in 2003, additionally as shown in Fig. 4 energy demand in 2010 was 11.5 TMT (Abusaa, 2010; Keiichi et al., 2009).

Libya's energy consumption mix has remained comparatively steady during the decade, with about $74 \%$ of energy demand being met by oil and $26 \%$ by natural gas in 2009 and changed to become $62 \%$ of oil and $38 \%$ of natural gas in 2010 (Wright, 2012). Oil will continue to be the dominant fuel, despite the share of gas which rose from $38 \%$ in 2010 to $41 \%$ of total energy demand by 2030 . The main increase in gas demand will occur in the energy sector between 2003 and 2030 , since $51 \%$ of total production will be gas-fired by the year 2030 (Affairs, 2010). 


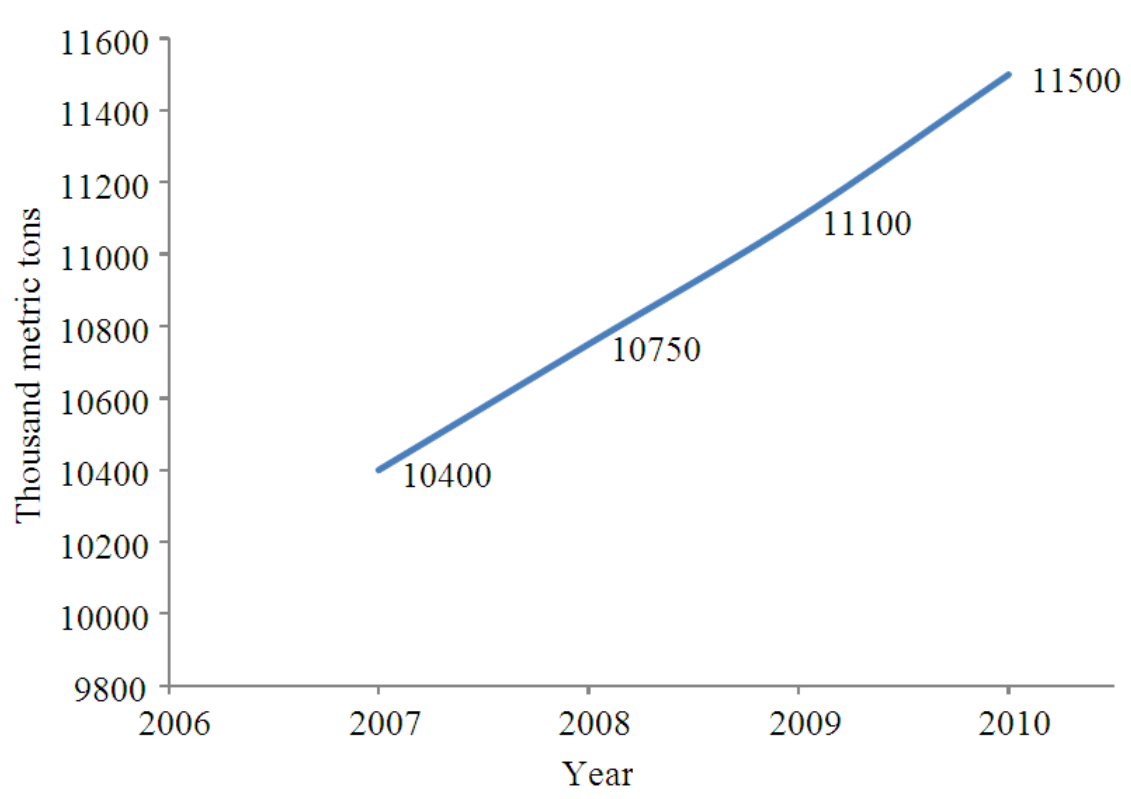

Fig. 4. Total energy demand in Libya, (Source: Based on data collected from The General Electricity Company of Libya GECOL)

\subsection{Energy Demand in Electricity Sector}

In 1965, Libya's total installed electricity capacity for electrical power amounted to only 70,000 Kilo Watt (KW). In Libya, total energy production stood at 157 million Kilo Watt Hours (KWh) in 1965, whereas the yearly consumption was estimated at $101 \mathrm{KWh}$ per capita. Capacity consumption stood at only $29 \%$ and the average annual rose in production between 1950 and 1965 amounted to the low figure of $11 \%$ (Waniss and Karlberg, 2007). In 1970 the peak demand was 150 megawatt $\left(1\right.$ megawatt $=10^{6}$ watts $)(\mathrm{MW})$, through 2003 Per capita consumption rose to about $2,798 \mathrm{KWh}$ while in the end of 2003; the peak was 3,340 MW. In the meantime, installed capacity raised to more than 5,759 MW in the end of 2010 (Hassin, 2009; LMERE, 2005). During the past decade, the electric energy sector has been established quite fast and this lead to the social and economic development (Ekhlat et al., 2007).

Oil is being used to generate more than $50 \%$ of energy. The share of natural gas in the electricity mix has been rising substantially since 2004. Because of its geographical location in between Tunisia, Algeria and Egypt-Libya is a key country for the development of the Mediterranean electricity circle. The Libyan network is very long $(2500 \mathrm{~km})$ but not very powerful. From an energy perspective, further expansion of the electricity grid and its integration in the region seems to be the country's major challenge.
Libya's demand is expected to grow rapidly. In order to meet this increase, the Libyan government is proposing consumption to double the power generation by 2014 and it will be more than two and half by the end of the year 2020. The overall number of customers in electric system in Libya is approximately 1.2 million, distributed between several categories which are the commercial sector, residential sector, industrial, agriculture and the public utilities (Mohammed, 2010). One issue leading to rapid energy demand growth is the fact that electricity is heavily subsidized, at perhaps onethird of the cost per kilowatt-hour.

Up to 2010, Libya's energy network involves approximately $2,290 \mathrm{~km}$ of $400-\mathrm{kV}$ (kilovolts) lines $13,706 \mathrm{~km}$ of $220-\mathrm{kV}$ lines $25,454 \mathrm{~km}$ of $66-\mathrm{kV}$ and $30 \mathrm{kV}$ lines (Mohammed, 2010). The total electricity production in The General Electricity Company of Libya (GECOL), which comes from 14 main power plants, is approximately 25.5 megawatt-h $=106$ watts $(\mathrm{MW})$ in the year 2007 (Affairs, 2010), increased to around 29 MWh in 2008 and $32.55 \mathrm{MWh}$ in 2010, compared to only $15 \mathrm{MWh}$ in 2000 (Waniss and Karlberg, 2007; El-Arroudi et al., 2009; Mohammed, 2010). However, There are plans to have a total installed capacity of 10 gigawatt (gigawatt $=10^{9}$ watts) $(\mathrm{GW})$ by the year 2015 (Affairs, 2010; GECOL, 2010). This signifies an average annual growth of $7-13 \%$. In the meantime, the 
energy consumption increased steadily over the past years and Libya has Africa's highest electricity Per capita consumption which was 5000 kilowatt $\mathrm{h}(\mathrm{kWh})$ in the year 2010 compared to only $2650 \mathrm{kWh}$ in the year 2000 as show in Fig. 5 (El-Arroudi et al., 2009; GECOL, 2010; Mohamed et al., 2013; Mohammed, 2010).

This growth is expected to continue as a result of the several new infrastructure projects which are planned. It will also continue to increase as the economy expands. GECOL has difficulties in meeting this demand with a suitable expansion of capacity; and power shortages are starting to necessitate programmed power cuts (Affairs, 2010). In 2010, the electrical sector distribution of energy consumption was approximately $14 \%$ for the commercial sector, $31.2 \%$ for the residential sector, $10 \%$ for the industrial, $10.7 \%$ for the agriculture, $11.7 \%$ for the public utilise, $19 \%$ for street lighting and $4.4 \%$ for others (Mohammed, 2010).

The information currently available in the public domain regarding renewable energy in Libya indicates that Libya is rich in solar and wind resource (Mohamed et al., 2013). Libya is located in the middle of North Africa with a huge area of $1,759,540 \mathrm{Km}^{2}$ and a long coast of a length of $1,900 \mathrm{~km}$ on the Mediterranean Sea with $88 \%$ of its area considered to be desert where there is a high potentiality of solar and wind energy which can be used to generate electricity thermal, photovoltaic and solar energy conversions. Moreover, it has been estimated that every year, each square kilometres $\left(\mathrm{km}^{2}\right)$ of desert in the Middle East/North
Africa region receives solar energy equivalent to 1.5 million barrels of crude oil (Mohamed et al., 2013; Trieb, 2011). In general, the average wind speeds ranges between 5 and 10 metres per second in number of the Libyan areas. Furthermore, Libya is exposed to dry and hot winds which blow several times during the year (Abohedma and Alshebani, 2010). In addition, the neighbouring countries to Libya have started to utilise the wind resource with different scales ranging from demonstration projects to commercial size wind farms (Khalifa, 1998), which is a clear indication of its feasibility in that region.

In fact, One of the main advantages of the wind energy in Libya is that there is a matching between the wind pattern and the pattern of the demand of the electric power in most places (Faraj, 2009; El-Osta, 1995). Recent studies have shown that the significance of desert and solar energy is as being the best alternative to traditional fusel fuel in Libya. However, one of the main renewable energy issues is the degree of matching between load patterns and renewable energy production. However, the demand of energy for air-conditioning is one of the main areas for energy consumption which is generally proportional to the availability of solar radiation during the day (Mohamed et al., 2013). The General Electricity Company of Libya (GECOL) has already begun contacts with international agencies and investors to use Clean Development Mechanism (CDM) for renewable energy growth.

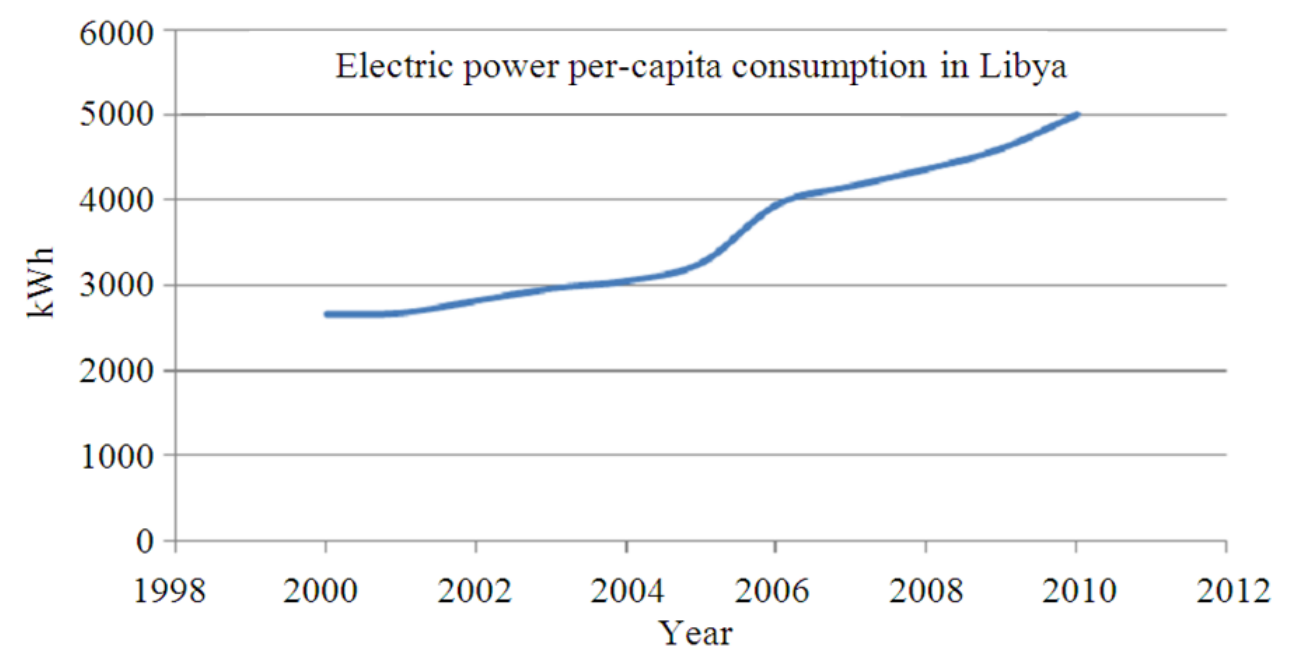

Fig. 5. Electric power per-capita consumption in Libya, (Source: Based on data collected from The General Electricity Company of Libya GECOL) 
In addition, the Libyan government has already issued a law to encourage foreign investors for all sectors (El-Arroudi et al., 2009). However, there is still an operating loss in the General Electricity Company of Libya (GECOL); this company receives its fuels at very highly subsidized prices. Indeed, the problems of managing the high growth rate in demand and financing the necessary heavy investments give The General Electricity Company of Libya (GECOL) a strong motivation to manage demand (Affairs, 2010).

\subsection{Libyan Renewable Energy}

The efforts to introduce a complete or partial alternative to the traditional sources (oil and natural gas) of electrical power are still continuingsince1976, in which the use of photovoltaic systems have started to supply electricity for a cathodic protection station for the oil pipe line connecting Dahra oil field with Sedra Port. In addition, four experimental stations in communication field was Installed in 1979. Moreover, in 1983 projects in the field of water pumping was started, where water was pumped for irrigation at EL-Agailat by a photovoltaic PV pumping system. The latest project was the construction of Al-Fattaih wind farm at the end of 2010 for production of $60 \mathrm{MW}$ as a first stage as in the project cost about 184 Million Libyan dinar. Table 2 shows the total accumulated installed PV systems in the field of communications, whereas, Table 3 shows the total accumulated PV system in all fields in Libya.

With regard to one of the main risks of renewable energy is the intermittent nature of these resources. However, many significant achievements have been made in the last few years, which make the renewable energy one of the strong alternatives to the traditional sources. The renewable energy role in any country mainly depends on the availability of the resources such as solar radiation, wind, biomass and geothermal. The most suitable way to determine the renewable energy utilisation is the assessment of load variation pattern. Accordingly, it is important to find the extent of matching between the local loads and renewable energy generation schedule. In this regard, it is known that in Libya most months are hot in general with a mean temperature of more than $35^{\circ} \mathrm{C}$ and this associated with a high rate of electricity consumption. Most of the months load consists of water pumps, electric fans and air conditioning. According to the renewable energy authority of Libya, there is a plan for renewable energy sharing with traditional energy as shown in Fig. 6. Additionally, renewable energy authority of Libya a project of installing
3000 solar water heaters in the house of worship Libya has already started and planning to install over 10,000 systems within the residential sector after issuing subsidiary law to subsidies the cost of SW heaters by up to $70 \%$.

With regard to the wind energy, it is known that Libya has a long coast, about $1900 \mathrm{~km}$ on the Mediterranean Sea. In addition, the potential of the wind is reasonable in several regions with the average speed at a 40 meter height is between $4-7.5 \mathrm{~m} \mathrm{sec}^{-1}$ as shown in Fig. 7. Saleh (2006), this speed can be harnessed economically. Wind energy in future could play an important role fulfilling energy needs and to the total electric energy demand.

In terms of solar energy, it could be argued that solar energy is the most important renewable energy resource, as Libya enjoys high level solar energy radiation. Solar energy is considered to be one of the main resources of energy due to the location of Libya on the cancer orbit line with exposure to the sun's rays throughout the year and with long hours during the day. The daily average solar radiation on a horizontal plane about 7.1 $\mathrm{kWh} / \mathrm{m}^{2} /$ day on the coast region in the north and 8.1 $\mathrm{kWh} / \mathrm{m}^{2} /$ day in the South region, with the average annual sun duration more than $3500 \mathrm{~h} /$ annum (h per year) (Saleh, 2006; Mohamed et al., 2013).

Furthermore, according to the renewable energy authority of Libya, the average hours of solar brightness is about 3000 and $3500 \mathrm{~h}$ per year and the average solar radiation is $6 \mathrm{kWh}$ per square meter per day. Based on Franz (Trieb, 2011; Mohamed et al., 2013) estimation of the equivalent of solar power generation to oil, the researcher calculated the daily equivalent as $=10^{6} \times$ $1.5 / 365 \approx 4110$ barrels of oil per day.

Table 2. Total installed PV systems in communication systems

\begin{tabular}{lcr}
\hline Company & Situation & $\mathrm{kWp}$ \\
\hline GPTC & 80 & 850 \\
Almadar & 172 & 1500 \\
Libyan & 57 & 330 \\
Oil Comp & 30 & 120 \\
Total & 393 & 2800 \\
\hline
\end{tabular}

Table 3. Total accumulated installed PV systems in Libya

\begin{tabular}{lr}
\hline Application & $\mathrm{kWp}$ \\
\hline Communication & 950 \\
Mobile & 1850 \\
Cathodic protection & 800 \\
Rural electrification & 725 \\
Water pumping & 120 \\
Grid connected & 30 \\
Total & 4475 \\
\hline
\end{tabular}




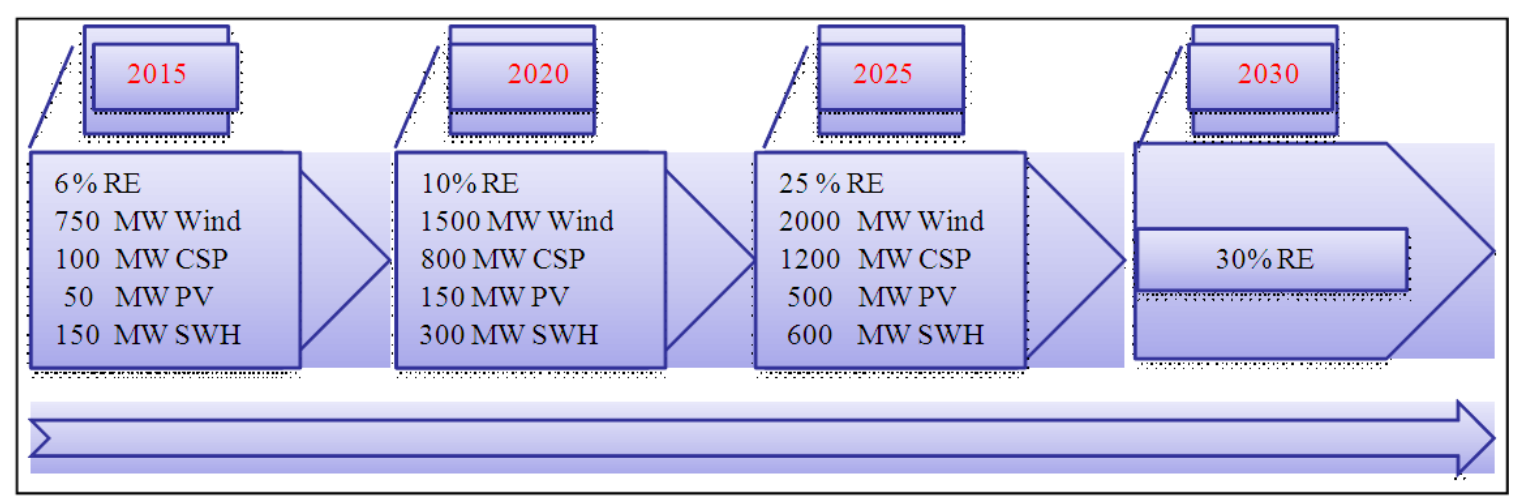

Fig. 6. Renewable energy share, (Source: The renewable energy authority of Libya)

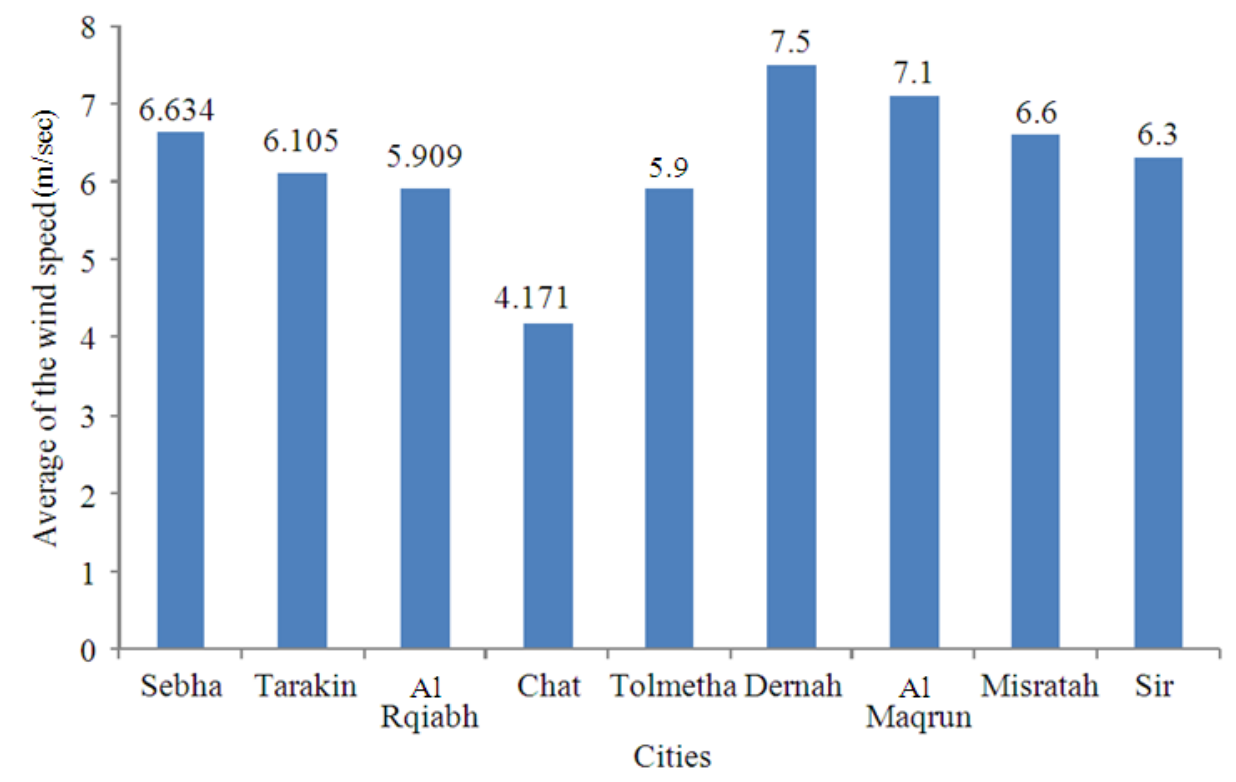

Fig. 7. Average of the wind in nine cities, (by Libyan Renewable Energy Authorityand Saleh (2006); Mohamed et al. (2013))

Therefore, if we use only 0.001 of Libyan area which means $\left(0.001 \times 1.7 \times 10^{6}\right)$ and this equivalent to $\left(1.7 \times 10^{6}\right.$ $\left.\mathrm{km}^{2} \times 0.001\right) \times 4110=6.986$ million barrels per day of energy. This number is fivetimes $(6.986 / 1.4$ production of May 2012) more than the current Libyan production of oil. Therefore, the wind and solar energy could provide a good complement to meet the peak loads and this in turn can be a good reason for encouraging wind and solar energy projects in Libya.

\section{CONCLUSION}

The study has presented the levels and mix of energy consumption and the expected future growth. This study has outlined the importance of developing the renewable energy sector in Libya. It has been found that renewable energy could provide an alternative source of energy and provide an opportunity to generate financial revenues as well as reduce the consumption levels of oil and natural gas. In addition, it has been found that energy demand is increasing in Libya and that renewable energy could be the solution to cover some of this demand without the need to build new fossil fuel stations. It is obvious, despite the recent political changes in Libya; renewable energy is still strategically of high importance. Solar and wind energy are considered the main sources of renewable energy in addition to wave and tidal energy. There is a need to attract investment in renewable technologies by enhancing the infrastructure and the existing regulations for foreign investments. 
Renewable energy technology is still within its early days in Libya; a clear strategy and time plan is still needed to take this sector forward particularly in relation to developing the skills and knowledge needed for installation and maintenance of such systems.

The authors would like to suggest the following recommendations for the development the renewable energy sector in Libya:

- To diversify the resources of energy in Libya by utilising the available renewable energy, particularly wind and solar

- Enhance the educational and training system to enable the necessary development in the sector

- Encourage local industries and investments related to the renewable energy sector to develop new employment opportunities, reduce pollution and provide energy savings for future generations

- Enhance the current regulations in order to attract foreign investors in the renewable energy sector

\section{REFERENCES}

Abohedma, M.B. and M.M. Alshebani, 2010. Wind load characteristics in Libya. World Acad. Sci. Eng. Technol., 63: 240-243.

Abusaa, F.M., 2010. The evaluation of welded alloy steel to hydrogen storage susceptibility. Proceedings of the International Renewable Energy Congress, Nov. 5-7, Sousse, Tunisia, pp: 522-525.

Affairs, F., 2010. Provision of technical support/services for an economical, technological and environmental impact assessment of national regulations and incentives for renewable energy and energy efficiency. The Ministry of Foreign Affairs of Denmark.

Ekhlat, M., I.M. Salah and E.N.M. Kreama, 2007. Development energy efficiency and renewable energy Libya-national study.

El-Arroudi, K., M. Moktar, B. El-Obadi, S. Sanoga and S. Osman, 2009. Demand Side Management in Libya-A Case Study of the General Electric Company of Libya. Transmission System Operation and Control Department, Tripoli-Libya.

Eljrushi, G.S. and J.N. Zubia, 1995. Photovoltaic power plant for the southern region of Libya. Applied Energy, 52: 219-227. DOI: 10.1016/0306-2619(95)00042-Q

El-Osta, W., 1995. Evaluation of wind energy potential in Libya. Applied Energy Special Proc., 2: 675-684.

Faraj, B., 2009. Alternative energy sources and its role in the Production of electric power in Libya. Research Centre for Renewable Energy and Water Desalination-Tajoura.
GECOL, 2010. General Electricity Company of Libya. Zawya.

Grein, M., B. Nordell and A.A. Mathnani, 2007. Energy consumption and future potential of renewable energy in North Africa. Gas, 1: 249-254.

Hassin, E., 2009. Total quality management in Libya: A study of its use in the electrical power generation industry. Glasgow Caledonian University.

Keiichi, K., I. Masakazu, V.D.F. Peter and K. Kurokawa, 2009. Energy from the Desert: Very Large Scale Photovoltaic System: Socio-Economic, Financial, Technical and Environmental Aspects. 1st Edn., Earthscan, London, ISBN-10: 1849770069, pp: 190.

Khalifa, Y., 1998. Wind atlas for the coastal region of Libya. M.Sc. Thesis Dissertation, Mechanical Engineering Department, Alfateh University.

LMERE, 2005. Libyan ministry of electricity and renewable energy. Annual Report 2005 up 2010.

Mandil, C., 2005. World Energy Outlook 2005: Middle East North Africa Insights Middle East North Africa. Paris.

Michel, C., 2013. Special supplement. Hay Demashque, Al-Hadba Al-Khadra, Tripoli, Libya.

Mohamed, A.M.A., A. Al-Habaibeh and H. Abdo, 2013. An investigation into the current utilisation and prospective of renewable energy resources and technologies in Libya. Renew. Energy, 50: 732-740. DOI: 10.1016/j.renene.2012.07.038

Mohammed, Z., 2010. CO2 Emission Factor for the electricity generation systems in Libya. Proceedings of the the Libyan International Conference on Electrical and Electronic Engineering, Oct. 23-26, Libya.

Saleh, I.M., 2006. Prospects of renewable energy in Libya. Al-Fateh University. Tripoli.

Tanaka, N., 2009. NaTURaL Gas: Market Review.

Trieb, F., 2011. Project Manager for the TRANS-CSP and the associated AQUA-CSP and MED-CSP report.

Waniss, O. and E. Karlberg, 2007. The Libyan Economy: Economic Diversification and International Repositioning, 1st Edn., Springer, ISBN-10: 3540464603, pp: 474.

Watkins, E., 2011. Libya's oil production hits 750,000 $\mathrm{b} / \mathrm{d}$ en route to full recovery. The University Cullece of Law of Tulas.

Wright, J., 2012. Libya: Country Analysis Briefs, 250 Park Avenue, Suite 2000. New York. 